\title{
Normothermia for pediatric and congenital heart surgery: an expanded horizon
}

\section{Ahmad Mahir Shamsuddin ${ }^{*}$, Ahmad Mohd Nikman' ${ }^{2}$,Saedah Ali ${ }^{2}$, Mohd Rizal Mohd Zain ${ }^{3}$, Abdul Rahim Wong ${ }^{4}$ and Antonio Francesco Corno ${ }^{1,3} t^{-}$}

\author{
1 Pediatric and Congenital Cardiac Surgery Unit, Department of Surgery, School of Medical Sciences, Universiti Sains Malaysia, Kubang Kerian, Kelantan, Malaysia \\ 2 Department of Anesthesia, School of Medical Sciences, Universiti Sains Malaysia, Kubang Kerian, Kelantan, Malaysia \\ ${ }^{3}$ Department of Pediatrics, School of Medical Sciences, Universiti Sains Malaysia, Kubang Kerian, Kelantan, Malaysia \\ ${ }^{4}$ Pediatric Cardiology, Hospital Raja Perempuan Zainab II, Kota Bharu, Kelantan, Malaysia
}

\section{Edited by:}

Oswin Grollmuss, Centre Chirurgical

Marie Lannelongue, France

Reviewed by:

Yves Durandy, Centre Chirurgical Marie-Lannelongue, France

Tsvetomir Loukanov, University of Heidelberg, Germany

\section{${ }^{*}$ Correspondence:}

Ahmad Mahir Shamsuddin, Pediatric and Congenital Cardiac Surgery Unit, Department of Surgery, School of Medical Sciences, Universiti Sains Malaysia, Health Campus, Kubang Kerian, Kelantan 16150, Malaysia e-mail: amahir@gmail.com

${ }^{+}$Present address:

Antonio Francesco Corno, East Midlands Congenital Heart Centre, Glenfield Hospital, Leicester, UK e-mail: tonycorno2@gmail.com
Cardiopulmonary bypass (CPB) in pediatric cardiac surgery is generally performed with hypothermia, flow reduction and hemodilution. From October 2013 to December 2014, 55 patients, median age 6 years (range 2 months to 52 years), median weight $18.5 \mathrm{~kg}$ (range $3.2-57 \mathrm{~kg}$ ), underwent surgery with normothermic high flow CPB in a new unit. There were no early or late deaths. Fifty patients $(90.9 \%)$ were extubated within $3 \mathrm{~h}, 3(5.5 \%)$ within $24 \mathrm{~h}$, and $2(3.6 \%)$ within $48 \mathrm{~h}$. Twenty-four patients $(43.6 \%)$ did not require inotropic support, 31 (56.4\%) received dopamine or dobutamine: $21 \leq 5 \mathrm{mcg} / \mathrm{kg} / \mathrm{min}, 85-10 \mathrm{mcg} / \mathrm{kg} / \mathrm{min}$, and $2>10 \mathrm{mcg} / \mathrm{kg} / \mathrm{min}$. Two patients $(6.5 \%)$ required noradrenaline $0.05-0.1 \mathrm{mcg} / \mathrm{kg} / \mathrm{min}$. On arrival to ICU and after 3 and $6 \mathrm{~h}$ and 8:00 a.m. the next morning, mean lactate levels were $1.9 \pm 09,2.0 \pm 1.2,1.6 \pm 0.8$, and $1.4 \pm 0.7 \mathrm{mmol} / \mathrm{L}(0.6-5.2 \mathrm{mmol} / \mathrm{L})$, respectively. From arrival to ICU to $8: 00$ a.m. the next morning mean urine output was $3.8 \pm 1.5 \mathrm{~mL} / \mathrm{kg} / \mathrm{h}$ $(0.7-7.6 \mathrm{~mL} / \mathrm{kg} / \mathrm{h})$, and mean chest drainage was $0.6 \pm 0.5 \mathrm{~mL} / \mathrm{kg} / \mathrm{h}(0.1-2.3 \mathrm{~mL} / \mathrm{kg} / \mathrm{h})$. Mean ICU and hospital stay were $2.7 \pm 1.4$ days (2-8 days) and $7.2 \pm 2.2$ days (4-15 days), respectively. In conclusion, normothermic high flow CPB allows pediatric and congenital heart surgery with favorable outcomes even in a new unit. The immediate post-operative period is characterized by low requirement for inotropic and respiratory support, low lactate production, adequate urine output, minimal drainage from the chest drains, short ICU, and hospital stay.

Keywords: cardiopulmonary bypass, congenital heart defects, congenital and pediatric heart surgery, hemodilution, high flow, modified ultrafiltration, normothermia, surgical outcomes

\section{INTRODUCTION}

Cardiopulmonary bypass (CPB) for pediatric cardiac surgery is generally performed with hypothermia, flow reduction, and hemodilution. The reasons historically given to justify the above technique were to maintain low metabolic status during the operation, to gain maximum tissue protection during $\mathrm{CPB}$, to have a relatively safe margin in situation of unexpected difficulties, and to provide adequate surgical exposure (1).

A large number of hospitals are still using the technique of deep hypothermia with circulatory arrest, justified by reduced duration of CPB in small infants, simplified cannulation and unencumbered operative field particularly for infants with anomalous venous connections (2).

However, the use of hypothermic CPB with flow reduction and hemodilution is associated with major side effects, with negative influence on the patients' outcomes. Because of this reason several hospitals, at least in Europe, have moved toward the use of normothermia for pediatric and congenital heart surgery $(1,3,4)$.

In a new unit like ours, with its inherent difficulties because of new staff and the lack of training available in a developing country, normothermic high flow $\mathrm{CPB}$ was introduced for pediatric and congenital heart surgery.
The aim of this prospective study was to analyze the results of the initial experience.

\section{MATERIALS AND METHODS}

From October 2013 to December 2014, 97 consecutive patients, median age 3.6 years (range 27 days to 52 years), with median body weight $12.1 \mathrm{~kg}$ (range $800 \mathrm{~g}$ to $62 \mathrm{~kg}$ ), underwent surgery for pediatric and congenital heart defects in our new unit.

Criteria for exclusion from this study were operation performed without the use of $\mathrm{CPB}$ or operation performed with the use of even a mild degree of hypothermia $\left(<35^{\circ} \mathrm{C}\right)$.

Fifty-five consecutive patients $(55 / 97=57 \%)$, median age 6.0 years (range 2 months to 52 years), with median body weight $18.5 \mathrm{~kg}$ (range $3.2-57.0 \mathrm{~kg}$ ), underwent surgery with normothermic high flow $\mathrm{CPB}$ and were prospectively included in the study.

Forty-two patients $(42 / 97=43 \%)$ were excluded from the study because they were operated on either without CPB (40 patients) or because the operation required $\mathrm{CPB}$ with a period of hypothermia $\left(<35^{\circ} \mathrm{C}\right)$ because of aortic surgery with flow reduction ( 2 patients).

The study was approved by the hospital ethical committee and parental informed consent was obtained for all patients. 


\section{CPB PROTOCOL}

The standard protocol for $\mathrm{CPB}$ was the following:

- priming with leukocyte-depleted blood (when blood required)

- controlled reoxygenation (5-9) in cyanotic patients with preoperative oxygen saturation $\leq 85 \%$

- normothermia: nasopharynx and rectal temperature maintained between 35.0 and $36.5^{\circ} \mathrm{C}$

- high flow: $\geq 3.0 \mathrm{~L} / \mathrm{m}^{2} \mathrm{BSA} / \mathrm{min}$

- hematocrit $\geq 30 \%$, aiming at a value at least $40 \%$ by the end of $\mathrm{CPB}$

- mixed venous oxygen saturation $\geq 65 \%$

- cold blood cardioplegia administered every $20 \mathrm{~min}$

- modified ultrafiltration $(10-15 \mathrm{~mL} / \mathrm{kg})$ at the end of $\mathrm{CPB}$

- administration of I.V. milrinone $(0.3 \mathrm{mcg} / \mathrm{kg} / \mathrm{min})$ from the end of $\mathrm{CPB}$

- administration of I.V. calcium gluconate $(300 \mathrm{mg} / \mathrm{kg} /$ day $)$ on arrival to ICU

- administration of I.V. frusemide ( $1-2 \mathrm{mg} / \mathrm{kg} /$ day) on arrival to ICU

Diagnoses and the surgical procedures are listed in Tables 1 and 2 .

The Basic and Comprehensive Aristotle Score (10) were used to assess the potential mortality and morbidity in our patient population.

\section{DATA COLLECTION}

All database regarding patients operated with normothermic CPB were prospectively recorded.

The overall outcomes of the operation included: survival, need for re-operation, ICU, and hospital stays.

Intra-operative data included duration of $\mathrm{CPB}$ and aortic cross-clamp, need for inotropic support, lactate level, and urine output.

Post-operative data included duration of mechanical ventilation, and type, dosage and duration of inotropic support; in addition lactate level, urine output, and chest drains bleeding were recorded on arrival to ICU, after 3 and $6 \mathrm{~h}$, and at 8:00 a.m. of the first post-operative day.

Our hospital does not have an intermediate step-down unit, and therefore the patients were discharged from ICU only when they were off ventilatory support, inotropes, and chest drains, and were transferred to the normal ward.

Data were expressed as mean $\pm \mathrm{SD}$.

\section{RESULTS}

The mean Basic Aristotle score (scale 1-5) was $3.1 \pm 0.8$ (range 15 ) and the mean Comprehensive Aristotle score (scale 1-10) was $6.2 \pm 1.7$ (range $3-10$ ).

There were no early or late deaths until the end of the follow-up period (December 2014).

Not one patient had clinically evident neurological deficit, and only one patient $(1 / 55=1.8 \%)$ with Down syndrome required reoperation because of wound infection caused by Staphylococcus aureus after repair of Tetralogy of Fallot.
Table 1 | List of diagnosis and associated defects.

\begin{tabular}{|c|c|c|}
\hline $\begin{array}{l}\text { Number of } \\
\text { cases }\end{array}$ & Diagnosis & Associated defects \\
\hline 24 & $\begin{array}{l}\text { Ventricular septal defects } \\
18 \text { DCJA } \\
2 \text { Perimembranous } \\
4 \text { Multiple VSDs }\end{array}$ & $\begin{array}{l}9 \text { AoV Regurgitation } \\
7 \text { RVOTO } \\
7 \text { Subaortic obstruction }\end{array}$ \\
\hline 8 & Atrial septal defect & $\begin{array}{l}4 \text { MV Regurgitation } \\
1 \text { Borderline LV } \\
1 \text { Dislodged occlusion } \\
\text { device }\end{array}$ \\
\hline 4 & MV regurgitation & $\begin{array}{l}3 \text { AoV regurgitation } \\
1 \mathrm{TV} \text { regurgitation }\end{array}$ \\
\hline 5 & Tetralogy of Fallot & \\
\hline 4 & AVSD & $\begin{array}{l}3 \text { partial } \\
1 \text { Complete }\end{array}$ \\
\hline 3 & $\begin{array}{l}\text { Anomalous pulmonary venous } \\
\text { connection }\end{array}$ & $\begin{array}{l}2 \text { partial } \\
1 \text { Total }\end{array}$ \\
\hline 2 & Obstructed RV-PA conduit & \\
\hline 1 & RVOTO & s/p TF repair elsewhere \\
\hline 1 & DORV, VSD, TGA, PS & \\
\hline 1 & $\begin{array}{l}\text { Mitral atresia } \\
\text { DORV } \\
\text { Hypoplastic LV } \\
\text { Restrictive inter-atrial } \\
\text { communication }\end{array}$ & \\
\hline 1 & $\begin{array}{l}\text { Situs inversus } \\
\text { Dextrocardia } \\
\text { Univentricular Heart } \\
\text { Bilateral superior vena cava } \\
\text { Right aortic arch }\end{array}$ & \\
\hline 1 & $\begin{array}{l}\text { DORV, severe PS, VSD, } \\
\text { hypoplastic PAs, right aortic arch }\end{array}$ & \\
\hline
\end{tabular}

AoV, aortic valve; ASD, atrial septal defect; AVSD, atrio-ventricular septal defect, $D C J A$, doubly committed juxta-arterial, DORV, double outlet right ventricle, LV, left ventricle, MV, mitral valve, PA, pulmonary artery; $P S$, pulmonary stenosis; $R V$, right ventricle; RVOTO, right ventricular outflow tract obstruction; TGA, transposed great arteries; TV, tricuspid valve; TF, Tetralogy of Fallot; VSD, ventricular septal defect.

Mean CPB time and aortic cross-clamp time were respectively $94 \pm 43 \mathrm{~min}$ (range $45-288 \mathrm{~min}$ ) and $46 \pm 24 \mathrm{~min}$ (range 0-102 $\mathrm{min}$ ).

Fifty patients $(50 / 55=90.9 \%)$ were weaned from mechanical ventilation and extubated within $3 \mathrm{~h}$ from ICU arrival, three $(3 / 55=5.5 \%)$ within $24 \mathrm{~h}$, and two $(2 / 55=3.6 \%)$ within $48 \mathrm{~h}$.

Twenty-four patients $(24 / 55=43.6 \%)$ did not require inotropic support. Thirty-one patients $(31 / 55=56.4 \%)$ received dopamine or dobutamine post-operatively: 21 of them $(21 / 31=67.7 \%)$ received dopamine or dobutamine $\leq 5 \mathrm{mcg} / \mathrm{kg} /$ min, $8(8 / 31=25.8 \%)$ received $5-10 \mathrm{mcg} / \mathrm{kg} / \mathrm{min}$, and 2 
Table 2 | List of surgical procedures.

\begin{tabular}{|c|c|c|}
\hline $\begin{array}{l}\text { Number of } \\
\text { procedures }\end{array}$ & Surgical procedures & Additional procedures \\
\hline 24 & VSD closure & $\begin{array}{l}7 \text { RVOT reconstruction } \\
7 \text { Subaortic resection } \\
\text { with septal myectomy } \\
2 \text { AoV repair }\end{array}$ \\
\hline 8 & ASD closure & $\begin{array}{l}4 \mathrm{MV} \text { repair } \\
1 \text { Device removal }\end{array}$ \\
\hline 4 & MV repair & $\begin{array}{l}1 \mathrm{MV} \text { replacement } \\
1 \mathrm{AoV} \text { repair } \\
1 \mathrm{TV} \text { repair }\end{array}$ \\
\hline 5 & TF repair & 1 RV-PA conduit \\
\hline 4 & AVSD repair & \\
\hline 3 & $\begin{array}{l}\text { Repair of anomalous pulmonary } \\
\text { venous connection }\end{array}$ & \\
\hline 2 & Conduit replacement & \\
\hline 1 & $\begin{array}{l}\text { RVOT reconstruction with RV-PA } \\
\text { conduit }\end{array}$ & \\
\hline 1 & $\begin{array}{l}\text { Intracardiac repair of DORV, VSD, } \\
\text { TGA, PS }\end{array}$ & \\
\hline 1 & $\begin{array}{l}\text { Atrioseptectomy, main PA division, } \\
\text { Bidirectional Glenn }\end{array}$ & \\
\hline 1 & $\begin{array}{l}\text { Atrioseptectomy, main PA division, } \\
\text { bilateral bidirectional Glenn }\end{array}$ & \\
\hline 1 & $\begin{array}{l}\text { modified Blalock-Taussig shunt } \\
\text { on CPB }\end{array}$ & \\
\hline
\end{tabular}

AoV, aortic valve; ASD, atrial septal defect; AVSD, atrio-ventricular septal defect; $C P B$, cardiopulmonary bypass; DORV, double outlet right ventricle; $M V$, mitral valve; $P A$, pulmonary artery; $P S$, pulmonary stenosis; $R V$, right ventricle; RVOT, right ventricular outflow tract; TF, Tetralogy of Fallot; TGA, transposed great arteries; TV, tricuspid valve; VSD, ventricular septal defect.

$(2 / 31=6.5 \%)$ required $>10 \mathrm{mcg} / \mathrm{kg} / \mathrm{min}$. Two patients $(2 / 31=$ $6.5 \%$ ) required additional noradrenaline $0.05-0.1 \mathrm{mcg} / \mathrm{kg} / \mathrm{min}$.

Mean lactate level at arrival to ICU, after $3 \mathrm{~h}$, after $6 \mathrm{~h}$ and 08:00 a.m. next morning was respectively $1.9 \pm 09,2.0 \pm 1.2,1.6 \pm 0.8$, and $1.4 \pm 0.7 \mathrm{mmol} / \mathrm{L}$ (range $0.6-5.2 \mathrm{mmol} / \mathrm{L}$ ).

Mean urine output from ICU arrival to 08:00 a.m. next morning was $3.8 \pm 1.5 \mathrm{~mL} / \mathrm{kg} / \mathrm{h}$ (range $0.7-7.6 \mathrm{~mL} / \mathrm{kg} / \mathrm{h}$ ).

Mean chest drains bleeding from ICU arrival to 08:00 a.m. next morning was $0.6 \pm 0.5 \mathrm{~mL} / \mathrm{kg} / \mathrm{h}$ (range $0.1-2.3 \mathrm{~mL} / \mathrm{kg} / \mathrm{h}$ ).

Mean ICU and hospital stays were respectively $2.7 \pm 1.4$ days (range 2-8 days) and 7.2 \pm 2.2 days (range 4-15 days).

\section{DISCUSSION}

Hypothermic $\mathrm{CPB}$ with hemodilution was introduced in pediatric cardiac surgery with the aims of decreasing the oxygen consumption and improving the distal body perfusion with the decreased blood viscosity due to hemodilution $(1,3,4)$. With the introduction of surgical repair of more complex congenital heart defects in small infants, the hypothermic CBP with flow reduction, and even deep hypothermia with circulatory arrest, gained widespread application because of the adequate surgical exposure allowed by the absence of blood and venous cannulas in the small operative field $(1,2,4,11,12)$.

Despite the good results obtained with hypothermic CPB, allowing the surgical repair of more complex congenital heart defects, over the years a large series of experimental and clinical studies reported extensive negative effects of hypothermia and flow reduction associated with hemodilution $(1,3,4,12-34)$, which are the following:

\section{AT THE CELLULAR LEVEL}

Decreased ATP levels were observed, as well as increased anaerobic metabolism, decreased intracellular $\mathrm{pH}$, increased lactate production, decreased glycogen level, decreased efficiency of membranebased ion pumps, increased cell swelling, decreased mitochondrial function, increased Calcium influx, and decreased intracellular enzyme function.

These damages mainly occur in the parenchymal cells (neurons and myocytes), the endothelial cells (systemic and pulmonary vascular systems), and the inflammatory cells (inflammatory response, ischemia/reperfusion injury).

\section{AT THE TISSUE LEVEL}

The metabolic and hormonal systems are affected in relation to blood glucose, adrenal stress response, level of circulating adrenaline and noradrenaline, release of insulin and peripheral utilization of glucose, serum potassium, release of neurotransmitters in response to ischemia, ability of receptors to bind and take up noradrenaline, complement activation, release of angiotensin, interleukins, cytokines, beta-endorphines, and anti-diuretic hormones. The vascular system is affected by endothelial injury, decreased cardiac output, increased systemic vascular resistance, renal vasoconstriction, and generalized tissue edema.

In the myocardium, rapid cooling contracture can occur, and the respiratory system can be affected by endothelial lung injury.

Renal function is impaired by decreased glomerular filtration, decreased renal cortical blood flow because of renal vasoconstriction with redistribution of intra-renal blood flow to the renal medulla, and depressed tubular function.

Neurologic damages were reported because of increased cerebral vascular resistance, decreased cerebral blood flow, decreased response to increase in $\mathrm{CO}_{2}$ tension, hypothalamic dysfunction (post-operative hyperthermia), appearance of choreoathetosis, seizures, and overall vulnerability to brain injuries and neurodevelopmental impairment.

The hematologic system is affected by left shift of the oxyhemoglobin dissociation curve, leukocyte aggregation and degranulation, and platelet function defect (shape change, aggregation).

The overall clinical consequences complicating the outcomes of pediatric and congenital heart surgery with conventional hypothermic $\mathrm{CPB}$ with flow reduction and hemodilution are low cardiac output syndrome (requiring inotropic support), pulmonary dysfunction (requiring respiratory support), metabolic derangement (with acidosis and renal failure), coagulation derangement (with excessive chest bleeding), and neurologic complications (with choreoathetosis, seizures, and neurodevelopmental impairment) $(1,3,4,12,15,18-24)$. 
All these negative reports derived from experimental and clinical studies motivated the search for alternative modality for perfusion in the pediatric population.

The two most important changes introduced in clinical practice were (1) the selective cerebral perfusion, in order to reduce the negative neurologic consequences of the circulatory arrest accompanying deep hypothermia $(2,11,12,35-39)$; (2) the reduced degree of hemodilution, with a higher hematocrit than used before $(31,33,34)$.

But the most evident modification of the conventional CPB with hypothermia and hemodilution was the introduction of normothermic high flow CPB with minimal hemodilution.

This technique of perfusion was first used in Paris, France, by Lecompte and Durandy (40), who later reported in the literature the use of their technique in a very large number of patients in pediatric heart surgery $(41,42)$; the direct exposure to this experience persuaded other surgeons to introduce the same technique in their clinical practice, and in few years the number of hospital using normothermic high flow CPB with limited hemodilution expanded across Europe (1, 3, 4, 43-49).

The basic principles are the use of high flow, with the pump flow maintained $\geq 3.0 \mathrm{~L} / \mathrm{m}^{2} \mathrm{BSA} / \mathrm{min}$, with the nasopharynx and rectal temperature maintained between 35.0 and $36.5^{\circ} \mathrm{C}$, and hematocrit maintained $\geq 30 \%$. These conditions are more close to the normal physiology, where the systemic flow is $3.0-5.5 \mathrm{~L} / \mathrm{m}^{2}$ B.S.A. $/ \mathrm{min}$, the temperature $37^{\circ} \mathrm{C}$, and the hematocrit $45 \%$.

The pump flow used in conventional CBP is $2.0-2.4 \mathrm{~L} / \mathrm{m}^{2}$ $\mathrm{BSA} / \mathrm{min}$ or $100-120 \mathrm{~mL} / \mathrm{min} / \mathrm{kg}$ of body weight, even if it is improperly called "full flow," and frequently is further reduced during the central part of the operation when requested by the surgeon to facilitate the surgical exposure, or even to circulatory arrest with deep hypothermia.

The combination of flow reduction, hypothermia, and hemodilutaion are responsible for all the difficulties observed in the post-operative course after pediatric and congenital heart surgery.

Additional modifications used in our experience, in addition to the technique of normothermic high flow CPB with limited hemodilution, were:

- priming with leukocyte-depleted blood (when blood required) The use of leukocyte-depleted blood was long time ago demonstrated to be one of the most important variable to reduce the ischemia/reperfuson damage associated with the CPB and the mycardial ischemia required for intracardiac repair $(50,51)$.

- "controlled" reoxygenation

The damaged induced by the hypoxia/reoxygenation injury were extensively studied with experimental and clinical studies (5-9, 52-61).

The technique of "controlled" reoxygenation was introduced in the clinical practice after extensive animals' studies. To reduce the oxygenation damage, the arterial $\mathrm{pO}_{2}$ at the beginning of $\mathrm{CPB}$ is slowly and progressively increased, reaching the full reoxygenation after $5 \mathrm{~min}$ of full flow. This technique was applied in our experience in all cyanotic patients with pre-operative oxygen saturation $\leq 85 \%$.

- modified ultrafiltration
The technique of modified ultrafiltration was introduced as one of the methods to reduce the inflammatory response caused by the CPB (62-69).

The mechanisms used by modified ultrafiltration are the following: removal of significant amounts of inflammatory mediators (IL-1, IL-6, TNF-alpha, C3a, and C5a), removal of excessive body water, and reduction in the quantity of circulating endotoxins.

The observed clinical advantages provided by modified ultrafiltration are improved intrinsic left ventricular systolic function, increased systemic blood pressure, decreased pulmonary artery pressure, and decreased requirement for inotropic and respiratory support in the early post-operative period (62-73).

In our experience, we applied modified ultrafiltration at the end of CPB in all patients, removing an amount of fluids between 10 and $15 \mathrm{~mL} / \mathrm{kg}$ according to the clinical needs.

This study with normothermic high flow CPB has resulted in favorable outcomes, even in our study population, represented by patients with generally poor conditions because of malnutrition, recurrent infections, and late referrals. Furthermore, the technique has been introduced in a new unit, without any previous experience in pediatric cardiac surgery, and with all limitations due to reduced manpower, limited resources, and a generalized low level of expertise in the field.

Nevertheless, our patients had good results, with generally short ICU and hospital stay, early extubation, low requirement of inotropic support, low lactate production, adequate urine output, and minimal drainage from the chest drains.

\section{POTENTIAL CONCERNS}

There are two potential concerns toward the use of normothermic, high flow, high hematocrit, $\mathrm{CPB}$ :

(a) reduced margin of safety against potential incidents on CPB (b) inadequate surgical exposure.

However, the advantages provided by this perfusion technique in the post-operative recovery overcome by far the potential risk of incidents $(44,45)$, and adequate exposure even in small cyanotic neonates can be obtained with appropriate venous cannulation and left heart venting $(1,40,43-45)$.

With regard to all the neurologic complications reported by the conventional $\mathrm{CPB}$, the normothermic, high flow, high hematocrit, $\mathrm{CPB}$ has been used with reported contradictory neurologic results, from the safety in relationship to the neurodevelopmental status (49) to the observation with comparison of pre-operative with post-operative magnetic resonance imaging suggesting that normothermic perfusion is associated with few new lesions following the surgical treatment (73).

\section{LIMITATIONS OF THE STUDY}

The main limitation of this study is the absence of a control group.

So far, no systematic randomized control trial has been performed to support normothermic high flow $\mathrm{CPB}$ versus hypothermic $\mathrm{CPB}$, but there is an increasing trend toward the use of normothermic $\mathrm{CPB}$, and no major adverse effects have been reported by any series on normothermic CPB. 
Randomized controlled clinical trials (70) are considered the gold standard (71) and would help define which of the two main techniques are superior; however, a prospective randomized clinical trial is not easily feasible because of several reasons:

(a) huge variability among the patient populations with congenital heart defects. For instance, the evaluation of the neurodevelopmental outcome (70) should take into consideration a substantial percentage of infants with pre-operative cerebral abnormalities (72)

(b) standardization of surgical procedures, with endless variable details, is very difficult to achieve

(c) minor or major differences in the post-operative values of inflammatory markers, neurological status, requirement and duration of inotropic and respiratory support, stay in ICU, etc., are dependent upon several variables in the patient management, all inter-related and inter-dependent, not necessarily correlated with the modality of $\mathrm{CPB}$

(d) after having used the "normothermic, high flow, high hematocrit" $\mathrm{CPB}$, and having seen the advantages over the conventional hypothermic techniques, with an extremely smooth and "physiologic" post-operative course, to consider for the patients a return to the hypothermic techniques has been considered by all surgeons as undesirable or unethical

\section{CONCLUSION}

Normothermic high flow CPB, close to normal physiology, allows pediatric and congenital heart surgery with favorable outcomes. The immediate post-operative period is characterized by low requirement for inotropic and respiratory support, low lactate production, adequate urine output, minimal losses from chest drains, short ICU, and hospital stay.

This CPB technique was introduced successfully in a new pediatric cardiac service with previous or little experience in congenital heart disease surgery.

\section{ACKNOWLEDGMENTS}

We would like to thank the perfusionists Ridzuan Wazil, Safuddin Mohd Yunus, and Mat Razali for the constant technical assistance with the cardiopulmonary bypass and modified ultrafiltration.

\section{REFERENCES}

1. Corno AF, Von Segesser LK. Is hypothermia necessary in pediatric cardiac surgery? Eur J Cardiothorac Surg (1999) 15:110-1. doi:10.1016/S1010-7940(98) 00291-7

2. Ungerleider RM, Shen I. Optimizing response of the neonate and infant to cardiopulmonary bypass. Semin Thorac Cardiovasc Surg Pediatr Card Surg Annu (2003) 6:140-6. doi:10.1053/pcsu.2003.50008

3. Caputo M, Bays S, Rogers CA, Pawade A, Parry AJ, Suleiman S, et al. Randomized comparison between normothermic and hypothermic cardiopulmonary bypass in pediatric open-heart surgery. Ann Thorac Surg (2005) 80:982-8. doi:10.1016/j.athoracsur.2005.03.062

4. Durandy Y. Warm pediatric cardiac surgery: European experience. Asian Cardiovasc Thorac Ann (2010) 18:386-95. doi:10.1177/0218492310376675

5. Corno AF, Samaja M. The reoxygenation phenomenon. J Thorac Cardiovasc Surg (1993) 105:373-4

6. Corno AF, Samaja M, Casalini S, Allibardi S. The effects of the rate of reoxygenation on the recovery of hypoxemic hearts. J Thorac Cardiovasc Surg (1995) 109:1250-1. doi:10.1016/S0022-5223(95)70212-1
7. Corno AF, Milano G, Samaja M, von Segesser LK. Myocardial damage induced by uncontrolled reoxygenation. Asian Cardiovasc Thorac Ann (2000) 8:34-7. doi:10.1177/021849230000800109

8. Milano G, Bianciardi P, Corno AF, Raddatz E, Morel S, von Segesser LK, et al. Myocardial impairment in chronic hypoxia is abolished by short aeration episodes: involvement of K+ATP channels. Exp Biol Med (Maywood) (2004) 229:1196-205.

9. Caputo M, Mokhtari A, Miceli A, Ghorbel MT, Angelini GD, Parry AJ, et al. Controlled reoxygenation during cardiopulmonary bypass decreases markers of organ damage, inflammation, and oxidative stress in single-ventricle patients undergoing pediatric heart surgery. J Thorac Cardiovasc Surg (2014) 148:792-801. doi:10.1016/j.jtcvs.2014.06.001

10. Lacour-Gayet F, Clarke D, Jacobs J, Gaynor W, Hamilton L, Jacobs M, et al. Aristotle committee. The Aristotle score for congenital heart surgery. Semin Thorac Cardiovasc Surg Pediatr Card Surg Annu (2004) 7:185-91. doi:10.1053/j.pcsu. 2004.02.011

11. Barratt-Boyes BG, Simpson M, Neutze JM. Intracardiac surgery in neonates and infants using deep hypothermia with surface cooling and limited cardiopulmonary bypass. Circulation (1971) 43(5 Suppl):I25-30. doi:10.1161/01.CIR.43. 5S1.I-25

12. Bellinger DC, Wernovsky G, Rappaport LA, Mayer JE Jr, Castaneda AR, Farrell $\mathrm{DM}$, et al. Cognitive development of children following early repair of transposition of the great arteries using deep hypothermic circulatory arrest. Pediatrics (1991) 87:701-7.

13. Terblanche J, Isaacson LC, Eales L, Barnard CN. Renal function during and immediately after profound hypothermia. Surgery (1961) 50:869-76.

14. Monroe RG, Strang RH, LaFarge CG, Levy J. Ventricular performance pressure volume relationship ona $\mathrm{O} 2$ consumption during hypothermia. Am J Physiol (1964) 206:67-73.

15. Baum D, Dillard DH, Porte D. Inhibition of insulin release in infants undergoing deep hypotermic cardiovascular surgery. N Engl J Med (1968) 279:1309-14 doi:10.1056/NEJM196812122792404

16. McConnell DH, White FN, Peters F, Nelson RL, Goldstein SM, Maloney JV, et al. Importance of alkalosis in maintenance of "ideal" blood $\mathrm{pH}$ during hypothermia. Surg Forum (1975) 26:263-5.

17. DuPlessis AJ, Jonas RA, Wypij D, Hickey PR, Riviello J, Wessel DL. Perioperative effects of alpha-stat versus $\mathrm{pH}$-stat strategies for deep hypothermic circulatory bypass in infants. J Thorac Cardiovasc Surg (1977) 114:991-1000. doi:10.1016/S0022-5223(97)70013-8

18. Landymore RW, Murphy DA, Longley WJ. Effects of cardiopulmonary bypass and hypothermia on pancreatic function and peripheral utilization of glucose. Can J Surg (1979) 22:248-50.

19. Swain JA, White FN, Peters RM. The effect of $\mathrm{pH}$ on the hypothermic ventricular fibrillation threshold. J Thorac Cardiovasc Surg (1984) 87:445-51.

20. Kurihara S, Sakai T. Effect of rapid cooling on mechanical and electrical responses in ventricular muscle of the guinea pig. J Physiol (1985) 361:361-78. doi:10.1113/jphysiol.1985.sp015650

21. Quiroga MM, Miyagishima R, Haendschen LC, Glovsky M, Martin BA, Hogg JC. The effect of body temperature on leukocyte kinetics during cardiopulmonary bypass. J Thorac Cardiovasc Surg (1985) 90:91-6.

22. Murkin JM, Farrar JK, Tweed WA, McKenzie FN, Guiraudon G. Cerebral autoregulation and flow/metabolism coupling during cardiopulmonary bypass: the influence of PaCO2. Anesth Analg (1987) 66:825-32. doi:10.1213/00000539198709000-00003

23. Greely WJ, Kern FH, Ungerleider RM, Boyd JL, Quill T, Smith LR. The effect of hypothermic cardiopulmonary bypass and total circulatory arrest on cerebral metabolism in neonates, infants and children. J Thorac Cardiovasc Surg (1991) 101:783-94.

24. Rady MY, Ryan T, Starr NJ. Early onset of acute pulmonary dysfunction after cardiovascular surgery: risk factors and clinical outcome. Crit Care Med (1997) 25:1831-9. doi:10.1097/00003246-199711000-00021

25. Corno AF. Evaluation of resting coronary blood flow and coronary flow reserve in infants after cardiac operations. J Thorac Cardiovasc Surg (1998) 116:182-3. doi:10.1016/S0022-5223(98)70267-3

26. Birdi L, Caputo M, Underwood M, Bryan AJ, Angelini GD. The effects of cardiopulmonary bypass temperature on inflammatory response following cardiopulmonary bypass. Eur J Cardiothorac Surg (1999) 16:540-5. doi:10.1016/ S1010-7940(99)00301-2 
27. Heltne JK, Koller ME, Lund T, Bert J, Rynning SE, Stangeland L. Dynamic evaluation of fluid shifts during normothermic and hypothermic cardiopulmonary bypass in piglets. Acta Anaesthesiol Scand (2000) 44:1220-5. doi:10.1034/j.13996576.2000.441006.x

28. Honore PM, Jacquiet LM, Beale RJ, Renauld JC, Valadi D, Noirhomme P. Effects of normothermia versus hypothermia on extravascular lung water and serum cytokines during cardiopulmonary bypass: a randomized, controlled trial. Crit Care Med (2001) 29:1903-9. doi:10.1097/00003246-200110000-00009

29. Clancy RR, McGaurn SA, Wernovsky G, Gaynor JW, Spray TL, Norwood WI. Risk of seizures in survivors of newborn heart surgery using deep hypothermic circulatory arrest. Pediatrics (2003) 111:592-601. doi:10.1542/peds.111.3.592

30. Wypij D, Newburger JW, Rappaport LA, DuPlessis AJ, Jonas RA, Wernovsky G. The effect of duration of deep hypothermic circulatory arrest in infant heart surgery on late neurodevelopment: the Boston circulatory arrest trial. J Thorac Cardiovasc Surg (2003) 126:1397-403. doi:10.1016/S0022-5223(03) 00940-1

31. Jonas RA, Wypij D, Roth SJ, Bellinger DC, Visconti KJ, DuPlessis AJ. The influence of hemodilution on outcome after hypothermic cardiopulmonary bypass: results of a randomized trial in infants. J Thorac Cardiovasc Surg (2003) 126:1765-74. doi:10.1016/j.jtcvs.2003.04.003

32. Brown KL, Ridout DA, Goldman AP, Hoskote A, Penny DJ. Risk factors for long intensive care unit stay after cardiopulmonary bypass in children. Crit Care Med (2003) 31:28-33. doi:10.1097/00003246-200301000-00004

33. Karl TR, Hall S, Ford G, Kelly EA, Brizard CP, Mee RB. Arterial switch with full-flow cardiopulmonary bypass and limited circulatory arrest: neurodevelopmental outcome. J Thorac Cardiovasc Surg (2004) 127:213-22. doi:10.1016/j. jtcvs.2003.06.001

34. Newburger JW, Jonas RA, Soul J, Kussman BD, Bellinger DC, Laussen PC. Randomized trial of hematocrit $25 \%$ versus 35\% during hypothermic cardiopulmonary bypass in infant heart surgery. J Thorac Cardiovasc Surg (2008) 135:347-54. doi:10.1016/j.jtcvs.2007.01.051

35. Bellinger DC, Wypij D, DuPlessis AJ, Rappaport LA, Riviello J, Jonas RA. Developmental and neurologic effects of alpha-stat versus $\mathrm{pH}$ stat strategies for ddep hypothermic cardiopulmonary bypass in infants. J Thorac Cardiovasc Surg (2001) 121:374-83. doi:10.1067/mtc.2001.111206

36. Goldberg CS, Bove EL, Devaney EJ, Mollen E, Schwartz E, Tindall S. A randomized clinical trial of regional cerebral perfusion versus deep hypothermic circulatory arrest: outcomes for infants with functional single ventricle. J Thorac Cardiovasc Surg (2007) 133:880-7. doi:10.1016/j.jtcvs.2006.11.029

37. Visconti KJ, Rimmer D, Gauvreau K, del Nido P, Mayer JE, Hagino I. Regional low-flow perfusion versus circulatory arrest in neonates: one-year neurodevelopmental outcome. Ann Thorac Surg (2006) 82:2207-13. doi:10.1016/j. athoracsur.2006.06.069

38. Dent CL, Spaeth JP, Jones BV, Schwartz SM, Glauser TA, Hallinan B. Brain magnetic resonance imaging abnormalities after the Norwood procedure using regional cerebral perfusion. J Thorac Cardiovasc Surg (2006) 131:190-7. doi:10. 1016/j.jtcvs.2005.10.003

39. Corno AF, Pozzi M. Safe innominate artery cannulation for cardiopulmonary bypass in neonates. Asian Cardiovasc Thorac Ann (2007) 15:528-30. doi:10.1177/ 021849230701500619

40. Durandy Y, Hulin S, Lecompte Y. Normothermic cardiopulmonary bvpass in pediatric surgery. J Thorac Cardiovasc Surg (2002) 123:194. doi:10.1067/mtc. 2001.120005

41. Durandy YD, Hulin S. Normothermic bypass in pediatric surgery: technical aspects and clinical experience with 1400 cases. ASAIO J (2006) 52:539-42.

42. Durandy YD, Younes M, Mahut B. Pediatric warm open heart surgery and prolonged cross-clamp time. Ann Thorac Surg (2008) 86:194-7. doi:10.1016/ j.athoracsur.2008.08.004

43. Milella L, Da Cruz E, Gajraj R, Corno AF. Computerized anaesthesia and normothermic perfusion in paediatric cardiac surgery. 2nd World Congress of Pediatric Cardiology and Cardiac Surgery. Honolulu, HI (1997). 376 p.

44. Corno AF. What are the best temperature, flow, and hematocrit levels for pediatric cardiopulmonary bypass? J Thorac Cardiovasc Surg (2002) 124:856-7. doi: $10.1067 / \mathrm{mtc} .2002 .126388$

45. Pouard P, Mauriat P, Ek F, Haydar A, Gioanni S, Laquay N, et al. Normothermic cardiopulmonary bypass and myocardial cardioplegic protection for neonatal arterial switch operation. Eur J Cardiothorac Surg (2006) 30:695-9. doi:10.1016/j.ejcts.2006.07.032
46. Corno AF. Normal temperature and flow: are the "physiological" values so scary? Eur J Cardiothorac Surg (2007) 31:756. doi:10.1016/j.ejcts.2007.01.009

47. Cassano V, Milella L. Warm surgery: our experience. Eur J Cardiothorac Surg (2007) 31:754-5. doi:10.1016/j.ejcts.2007.01.015

48. Caputo MD, Patel N, Angelini GD, de Siena P, Stoica S, Parry AJ, et al. Effect of normothermic cardiopulmonary bypass on renal injury in pediatric cardiac surgery: a randomized controlled trial. J Thorac Cardiovasc Surg (2011) 142:1114-21. doi:10.1016/j.jtcvs.2011.08.008

49. Poncelet AJ, van Steenberghe M, Moniotte S, Detaille T, Beauloye C, Bertrand L, et al. Cardiac and neurological assessment of normothermia/warm blood cardioplegia vs hypothermia/cold crystallolid cardioplegia in pediatric cardiac surgery. Eur J Cardiothorac Surg (2011) 40:1384-90. doi:10.1016/j.ejcts. 2011.03.047

50. Davtyan HG, Corno AF, Laks H, Bhuta S, Flynn WM, Laidig C, et al. Long-term neonatal heart preservation. J Thorac Cardiovasc Surg (1988) 96:44-53.

51. Breda MA, Drinkwater DC, Laks H, Bhuta S, Corno AF, Davtyan HG, et al. Prevention of reperfusion injury in the neonatal heart with leukocyte-depleted blood. J Thorac Cardiovasc Surg (1989) 97:654-65.

52. Corno AF, Motterlini R, Brenna L, Santoro F, Samaja M. Ischaemia/reperfusion in the posthypoxaemic re-oxygenated myocardium: haemodynamic study in the isolated perfused rat heart. Perfusion (1993) 8:113-8. doi:10.1177/ 026765919300800115

53. Samaja M, Casalini S, Allibardi S, Corno AF, Chierchia S. Regulation of bioenergetics in $\mathrm{O}_{2}$-limited isolated rat hearts. J Appl Physiol (1994) 77:2530-6.

54. Milano G, Corno AF, De Jong JW, von Segesser LK, Samaja M. Tolerance of isolated rat hearts to low-flow ischemia and hypoxia of increasing duration: protective role of down-regulation and ATP during ischemia. Mol Cell Biochem (2001) 226:141-51. doi:10.1023/A:1012708324876

55. Corno AF, Milano G, Samaja M, Tozzi P, von Segesser LK. Chronic hypoxia: a model for cyanotic heart defects. J Thorac Cardiovasc Surg (2002) 124:105-12. doi:10.1067/mtc.2002.121302

56. Milano G, Corno AF, Lippa S, von Segesser LK, Samaja M. Chronic and intermittent hypoxia induce different degrees of myocardial tolerance to hypoxiainduced dysfunction. Exp Biol Med (Maywood) (2002) 227:389-97.

57. Silverman NA, Kohler J, Levitsky S, Pavel DG, Fang RB, Feinberg H. Chronic hypoxemia depresses global ventricular function and predisposes the depletion of high-energy phosphates during cardioplegic arrest: implications for surgical repair of cyanotic congenital heart defects. Ann Thorac Surg (1984) 37:304-8. doi:10.1016/S0003-4975(10)60735-7

58. Najm HK, Wallen WJ, Belanger MP, Williams WG, Coles JG, Van Arsdell GS Does the degree of cyanosis affect myocardial adenosine triphosphate levels and function in children undergoing surgical procedures for congenital heart disease? J Thorac Cardiovasc Surg (2000) 119:515-24. doi:10.1016/S0022-5223(00) 70131-0

59. Imura H, Caputo M, Pawade A, Angelini GD, Suleiman MS. Agedependent and hypoxia-related differences in myocardial protection during pediatric open heart surgery. Circulation (2001) 103:1551-6. doi:10.1161/01. CIR.103.11.1551

60. Hovels-Gurich HH, Schumaker K, Vazquez-Jimenez JF, Qing M, Huffmeier U, Buding B, et al. Cytokine balance in infants undergoing cardiac operation. Ann Thorac Surg (2002) 73:601-8. doi:10.1016/S0003-4975(01)03391-4

61. Modi P, Imura H, Caputo M, Pawade A, Angelini GD, Suleiman MS. Cardiopulmonary bypass-induced myocardial reoxygenation injury in pediatric patients with cyanosis. J Thorac Cardiovasc Surg (2002) 124:1035-6. doi:10.1067/mtc. 2002.122536

62. Naik SK, Knight A, Elliott MJ. A prospective randomized study of a modified technique of ultrafiltration during pediatric open-heart surgery. Circulation (1991) 84(5 Suppl):III422-31.

63. Elliott MJ. Ultrafiltration and modified ultrafiltration in pediatric open heart operations. Ann Thorac Surg (1993) 56:1518-22. doi:10.1016/0003-4975(93) 90744-3

64. Davies MJ, Nguyen K, Gaynor JW, Elliott MJ. Modified ultrafiltration improves left ventricular systolic function in infants after cardiopulmonary bypass. J Thorac Cardiovasc Surg (1998) 115:361-9. doi:10.1016/S0022-5223(98)70280-6

65. Li J, Hoschtitzky A, Allen ML, Elliott MJ, Redington AN. An analysis of oxygen consumption and oxygen delivery in euthermic infants after cardiopulmonary bypass with modified ultrafiltration. Ann Thorac Surg (2004) 78:1389-96. doi:10.1016/j.athoracsur.2004.02.032 
66. Kuratani N, Bunsangjaroen P, Srimueang T, Masaki E, Suzuki T, Katogi T. Modified versus conventional ultrafiltration in pediatric cardiac surgery: a metaanalysis of randomized controlled trials comparing clinical outcome parameters. J Thorac Cardiovasc Surg (2011) 142:861-7. doi:10.1016/j.jtcvs.2011.04.001

67. Harvey B, Shann KG, Fitzgerald D, Mejak B, Likosky DS, Puis L, et al. International pediatric perfusion practice: 2011 survey results. J Extra Corpor Technol (2012) 44:186-93.

68. Zhou G, Feng Z, Xiong H, Duan W, Jin Z. A combined ultrafiltration strategy during pediatric cardiac surgery: a prospective, randomized, controlled study with clinical outcomes. J Cardiothorac Vasc Anesth (2013) 27:897-902. doi:10.1053/j.jvca.2013.01.006

69. Türköz A, Tunçay E, Balci ST, Can MG, Altun D, Türköz R, et al. The effect of modified ultrafiltration duration on pulmonary functions and hemodynamics in newborns and infants following arterial switch operation. Pediatr Crit Care Med (2014) 15:600-7. doi:10.1097/PCC.0000000000000178

70. De Leval MR. Because we can, should we ...? Eur J Cardiothorac Surg (2006) 30:693-4. doi:10.1016/j.ejcts.2006.09.004

71. Sade RM. "Surgical research or comic opera" redux. Ann Thorac Surg (2006) 82:1173-4. doi:10.1016/j.athoracsur.2006.06.063

72. Mahle WT, Tavani F, Zimerman RA, Nicolson SC, Galli KK, Gaynor JW, et al. An MRI study of neurological injury before and after congenital heart surgery. Circulation (2002) 106:I109-14.
73. Durandy Y, Rubatti M, Couturier R, Rohnean A. Pre- and post-operative magnetic resonance imaging in neonatal arterial switch operation using warm perfusion. Artif Organs (2011) 35:1111-25. doi:10.1111/j.1525-1594.2011.01325.x

Conflict of Interest Statement: The authors declare that the research was conducted in the absence of any commercial or financial relationships that could be construed as a potential conflict of interest.

Received: 15 February 2015; paper pending published: 09 March 2015; accepted: 14 March 2015; published online: 28 April 2015.

Citation: Shamsuddin AM, Nikman AM, Ali S, Zain MRM, Wong AR and Corno AF (2015) Normothermia for pediatric and congenital heart surgery: an expanded horizon. Front. Pediatr. 3:23. doi: 10.3389/fped.2015.00023

This article was submitted to Pediatric Cardiology, a section of the journal Frontiers in Pediatrics.

Copyright (c) 2015 Shamsuddin, Nikman, Ali, Zain, Wong and Corno. This is an openaccess article distributed under the terms of the Creative Commons Attribution License (CC BY). The use, distribution or reproduction in other forums is permitted, provided the original author(s) or licensor are credited and that the original publication in this journal is cited, in accordance with accepted academic practice. No use, distribution or reproduction is permitted which does not comply with these terms. 